Citation: Sutherland, K. (2006). A standards-based framework for orienting new academics. A paper presented at the Improving University Teaching Conference, Dunedin, July 3-6, 2006. Proceedings on CD-Rom.

\title{
Title
}

A standards-based framework for orienting new academics

\author{
Author \\ Dr Kathryn Sutherland \\ Victoria University of Wellington \\ PO Box 600, Wellington \\ New Zealand. \\ Email: Kathryn.Sutherland@vuw.ac.nz \\ Phone: +64 44635795
}

\begin{abstract}
New academic staff/faculty begin with varying degrees of teaching, research and administrative experience, as well as with different cultural backgrounds and expectations. Often, the university's academic or faculty development unit (ADU) is charged with supporting and orienting them, sometimes in conjunction with Human Resources (HR) and/or the academic's own department. This research considers the role of ADUs in supporting new academic staff, and in particular investigates the introductory courses in teaching and learning designed to do this. Many universities now mandate new academics' participation in such courses, but how much accountability is there for the quality of these programmes and their impact on academics' practice and students' learning? While research into the impact of academic development is prevalent in Australia and the UK, in particular, very little has been done in New Zealand. Thus, this paper provides an overview of the eight New Zealand universities' programmes, and looks in-depth at the programme at one New Zealand university. It proposes a theory-driven, researchled, contextually responsive framework for the development of standards-based introductory programmes for new academics in New Zealand universities.
\end{abstract}




\section{A standards-based framework for orienting new academics}

\section{Introduction}

New academic staff in New Zealand universities face competing demands on their time and energies, in a rapidly changing tertiary sector. As they orient themselves to their new work environment, with new colleagues, roles, norms, and expectations, the group charged with supporting them is usually the university's academic development unit (ADU), sometimes in conjunction with Human Resources staff and the academic's own department or school. The challenge for New Zealand ADUs (and the universities in general) is to create introductory academic development and orientation programmes which fulfil the academics' immediate perceived needs of survival (Nyquist, et.al., 1999) and socialisation (Knight and Trowler, 2000; Staniforth and Harland, in press), while also encouraging new academics to take a scholarly (Glassick et.al., 1997) and professional (HEA, n.d.) approach to their work. This paper examines the introductory programmes for new academics at New Zealand's eight universities, in light of the New Zealand Tertiary Education Commission's call for the tertiary sector to "develop professional standards, to consider the application of professional qualifications and to build better understanding about the nature of effective teaching and learning" (STEP, p. 10). It proposes a theory-driven, research-led, and contextually responsive framework for the development of standards-based introductory academic development programmes for new academics in New Zealand universities.

\section{Method}

In March 2006, the Directors (or representative) of all eight New Zealand university ADUs were asked to verify, by email or phone, information on the elements of introductory academic development programmes for new academic staff ${ }^{1}$. (This paper looks specifically at the two- to five-day introductory programmes on university teaching and learning (IULT), not at universitywide induction or orientation programmes for all staff (general, allied and academic), nor at Postgraduate Certificates in Higher Education/Tertiary Teaching, tutor training, or supervisor training programmes.) The information on these programmes was publicly available through each university's website, and directors were also asked for publicly available (ie, on a website or in a published programme flyer) information on the following: specific offerings for new Maori or new international academic staff; a statement of goals or learning outcomes behind the programmes; and formalised structures or approaches for discipline-specific learning for participants.

Directors or representatives from all eight universities responded, and the information on the programmes was then summarised to identify common components, duration, mandatory requirements and objectives. Then, the published programmes and their objectives were analysed against "The UK Professional Standards Framework for teaching and supporting learning in higher education" (HEA, n.d.) and Glassick, et.al.'s (1997) standards of scholarly work to determine fitness for espoused purpose. One programme, at Victoria University of Wellington (the author's institution), was also looked at in more depth, and included consideration of the following data sources:

- Course evaluation data from participants in the last three years of the programme: $n=19$ responses from 29 participants in $2004(66 \%) ; n=27$ responses from 50 participants in 2005 (54\%); and $n=40$ responses from 57 participants in $2005(69 \%)$

- Follow-up phone calls to participants in the 2004 programme: $n=22$ of 26 participants $(85 \%)$

\footnotetext{
${ }^{1}$ This information was originally compiled as a summary for the Foundations of University Teaching and Learning Colloquia in Adelaide in 2003 and 2004 (Sutherland 2003; 2004) and is available online through the Foundations Colloquium Website: http://www.flinders.edu.au/teach/foundations/colloquium2003/Presentations/NZExpFoundations.doc.
} 
- Focus groups with self-selected programme participants in $2004(n=8)$ and $2005(n=5)$.

- Summarised data from an informal goal-setting exercise completed on the first day of the 2006 programme $(n=30$ responses from 46 participants $=65 \%)$.

The proposed ideas for a "Draft Framework for the Development of Standards-Based Introductory Programmes for New Academics in New Zealand Universities" were then constructed based on this analysis of existing programmes, the case study at Victoria University of Wellington, and what the research indicates is evidence-based and theory-driven best practice in other countries.

\section{What the research says new academics need}

There is a considerable international literature on the induction, socialisation and orientation of new academic staff to university work environments, from many theoretical perspectives. Many researchers in the UK and Australia, in particular, suggest that a discipline-based approach to inducting, orienting and training new university teachers is crucial (Reid, 2002; Knight and Trowler, 2000; Gibbs, 1996; Staniforth and Harland, in press) though often very hard to achieve (Boud, 1999). Most research on generic ADU programme offerings also implies a theoretical underpinning, if not an explicit theoretical framework, that encourages new staff to take a deep approach to learning about teaching (Ramsden, 2003) and to change their conceptions of learning about teaching (Ho, et.al, 2001), in the belief that these changes will subsequently have an impact on student learning (Knight and Trowler, 2000; Dearn, et.al., 2002; Gibbs and Coffey, 2004).

Others, often following Boyer's inclusive view of scholarship (Boyer, 1990) advocate for a less dualistic approach to induction and training that does not separate teaching and research but takes a more holistic view of the academic's role (Luby, cited in Dearn, 2002; Roche, 2001; Nicholls, 2005). However, very little research, if any, on the impact of New Zealand introductory programmes or their theoretical frameworks, has been published on the New Zealand university context. Prebble et.al.'s (2004) synthesis of the research on the "Impact of Student Support Services and Academic Development Programmes on Student Outcomes In Undergraduate Tertiary Study" found only three New Zealand-based research studies exploring the link between academic development and outcomes for teachers or students. None of the three looked directly at initial academic development programmes for new academic staff in New Zealand universities. So, what do new academics in New Zealand universities receive in terms of induction, orientation or introduction to their new jobs, roles, environments and/or careers?

\section{What the New Zealand introductory programmes offer}

All eight New Zealand university ADUs offer an initial academic development programme for new academics, most commonly an "Introduction to University Teaching and Learning" (IULT) programme, running anywhere from two to five days, or 12 to 30 hours. Five of the eight universities offer new academics a certificate of completion or attendance (in one university the certificate has New Zealand Qualifications Authority approval and attracts per-student funding (EFTS) from the government) $)^{2}$. Half of the IULT programmes are mandatory for academic staff new to teaching in a university environment.

All eight New Zealand IULT programmes feature common components, as summarised in Table 1, below. The most common session is Assessment (which means Testing and Grading, in North ${ }^{2}$ All 8 universities also offer (or have formal links with another university which offers) a PG Certificate in Higher Education, but
this paper does not deal with these qualifications, except in noting how IULT programmes articulate into the PG Certs. 
America), offered by all eight universities, followed closely by Lecturing, Student Learning/Support and a Powhiri - a formal indigenous welcome on to the university marae/meeting place - (seven of eight universities). Six of the eight universities offer sessions on Course Design, Small-group Teaching, Evaluation, Teaching-Related Policy and Supervision. Five offer sessions on the Treaty of Waitangi, E-learning/Flexible/Online Learning, Theories of Teaching and Learning, and Teaching International Students. Four offer a session on Teaching Portfolios, and two incorporate a session on Research into their introductory programmes.

Table One: Common Features of New Zealand IULT Programmes for New Academics

\begin{tabular}{|c|c|c|c|c|c|c|c|c|c|}
\hline Session Topics & Uni 1 & Uni 2 & Uni 3 & Uni 4 & Uni 5 & Uni 6 & Uni 7 & Uni 8 & No. \\
\hline Assessment & " & ! & ! & ! & ! & 口 & " & ! & $8 / 8$ \\
\hline Lecturing & - & $\square$ & $\square$ & & - & - & - & - & $7 / 8$ \\
\hline Student learning/ support & - & - & & $\square$ & - & - & - & - & $7 / 8$ \\
\hline Powhiri* & - & - & 口 & - & - & - & - & & $7 / 8$ \\
\hline Course Design & a & घ & - & & - & & $\square$ & - & $6 / 8$ \\
\hline Small-group teaching & & ! & - & & - & - & - & - & $6 / 8$ \\
\hline Supervision* ${ }^{*}$ & - & 匹 & 匹 & 匹 & - & 匹 & & & $6 / 8$ \\
\hline Policy session & च & $\square$ & & & I & I & 口 & a & $6 / 8$ \\
\hline Evaluation of teaching & - & घ & & - & & 口 & $\square$ & - & $6 / 8$ \\
\hline E-learning & $\square$ & & & $\square$ & - & घ & - & & $5 / 8$ \\
\hline Treaty of Waitangi* & a & च & च & 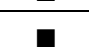 & - & & & & $5 / 8$ \\
\hline $\begin{array}{l}\text { Theories of teaching and } \\
\text { learning }\end{array}$ & - & 曰 & - & & - & & - & & $5 / 8$ \\
\hline Teaching International Students & - & & - & - & & - & - & & $5 / 8$ \\
\hline Developing a Teaching Portfolio & - & " & & & & - & - & & $4 / 8$ \\
\hline Research $^{* *}$ & $\bar{\square}$ & & & & - & & & & $2 / 8$ \\
\hline & & & & & & & & & \\
\hline Mandatory & No & Soon & No & Yes & Yes & No & No & Yes & $4 / 8$ \\
\hline Hours & 22.5 & 14 & 18 & 30 & 22.5 & 12 & 21 & 16.5 & $\begin{array}{l}19.5 \\
\text { Avg }\end{array}$ \\
\hline
\end{tabular}

* The Powhiri, Treaty of Waitangi and Supervision sessions are not always offered as part of the two or three-day "Introduction to Teaching and Learning" programme, but are usually run in the same week.

** Other universities besides the two indicated in the table may offer sessions on Research at other times, but the only ones recorded here are those that offer a Research session explicitly as part of the introductory programme.

In addition to the sessions listed above, several universities offer sessions that do not appear to be offered elsewhere. They are listed here to demonstrate the diversity of programmes on offer: Microteaching, Learning and Language, Teaching Outside the Box (Creative thinking), Scholarship of Teaching, Facilitating Laboratory Sessions, Developing Reflection, Problembased Learning, Using and Assessing Group Projects, Using Role-play for Teaching, Learning and Assessment, Diversity in Learning and Teaching, How to Help Difficult Students, Stories About Good Teaching.

\section{Developing Standards for the New Zealand IULT Programmes}

Table One identifies commonalities in New Zealand IULT programmes as well an overview of the types and diversity of content. The next step towards ensuring that these programmes meet new academics' needs, reflect the best of what is happening in other countries, and respond to the uniqueness of the New Zealand tertiary environment, should be to develop common standards across these programmes. In the UK, the Higher Education Academy, in conjunction with various UK higher education bodies, has developed the "UK Professional Standards Framework for Teaching and Supporting Learning in Higher Education”. This framework has been developed "for institutions to apply to their professional development programmes and 
activities and thus demonstrate that professional standards for teaching and supporting learning are being met" (HEA, n.d., p. 2).

One step towards developing a comparable New Zealand framework (for IULT programmes, if not for all academic development programmes) is to analyse our current IULT programme content, objectives, and assessment (if any) against the UK framework. The UK framework suggests six Areas of Activity, six types of Core Knowledge and five Professional Values to which higher education institutions might apply "their learning outcomes and assessment activities within the institution's professional development programme" (HEA, n.d., p. 2). Thus, Table Two offers an analysis of the New Zealand IULT sessions against the UK "Areas of Activity," and Table Three considers which sessions in the New Zealand programmes align with the six "Core Knowledge" areas in the UK framework.

Table Two: NZ Programme Offerings which Support UK Areas of Activity

\begin{tabular}{|l|l|}
\hline New Zealand Session Topics & UK Professional Standards Framework Areas of Activity \\
\hline $\begin{array}{l}\text { Course Design } \\
\text { Theories of Teaching and Learning } \\
\text { E-learning }\end{array}$ & Design and planning of learning activities and/or programmes of study \\
\hline $\begin{array}{l}\text { Lecturing } \\
\text { Student Learning/Support } \\
\text { Small Group Teaching } \\
\text { Theories of Teaching and Learning } \\
\text { E-learning }\end{array}$ & \\
Teaching International Students & Teaching and/or supporting student learning \\
\hline Assessment & Assessment and giving feedback to learners \\
\hline $\begin{array}{l}\text { Student Learning/Support } \\
\text { Supervision } \\
\text { Policy session }\end{array}$ & Developing effective environments and student support and guidance \\
\hline Research & \\
\hline $\begin{array}{l}\text { Evaluation of Teaching } \\
\text { Developing a Teaching Portfolio }\end{array}$ & Evaluation of practice and continuing professional development \\
\hline
\end{tabular}

It seems that the workshops and sessions offered across all eight New Zealand universities cover all six areas of activity specified by the HEA framework (see Table Two). When it comes to the core knowledge and professional values identified by the UK Professional Standards Framework, however, the New Zealand programmes appear to be lacking in three key areas (see Table Three and Figure One).

Table Three: NZ Programme Offerings Which Support UK Core Knowledge Areas

\begin{tabular}{|l|l|}
\hline New Zealand Session Topics & UK Professional Standards Framework Core Knowledge \\
\hline Research & The subject material \\
\hline & $\begin{array}{l}\text { Appropriate methods for teaching and learning in the subject area and at } \\
\text { the level of the academic programme }\end{array}$ \\
\hline Theories of teaching and learning & How students learn, both generally and in the subject \\
\hline E-learning & The use of appropriate learning technologies \\
\hline $\begin{array}{l}\text { Evaluation of teaching } \\
\text { Developing a Teaching Portfolio }\end{array}$ & Methods for evaluating the effectiveness of teaching \\
\hline & $\begin{array}{l}\text { The implications of quality assurance and enhancement for professional } \\
\text { practice }\end{array}$ \\
\hline
\end{tabular}

First, there is no obvious link to "the implications of quality assurance and enhancement for 
professional practice" in any of the New Zealand programmes (at least not from their published timetables, objectives or course descriptions). Second, very few of the New Zealand programmes appear to dedicate space and time for academics to develop discipline-specific knowledge about teaching and learning during their IULT programmes. In fact, it appears that only one university (AUT) offers a formalised discipline-specific programme for new staff, although it is not mandatory and is targeted mainly at staff on casual, part-time, hourly paid or temporary contracts. The AUT website describes it as a "one-day workshop followed by a mentoring process which enables participants the opportunity to develop questions and seek answers to them over the course of one semester. The process involves groups of academic staff from within the same faculty meeting with a facilitator for one hour once a month and some peer observation and feedback." (http://www.aut.ac.nz/staff/cepd/).

Third, the New Zealand introductory programmes do not necessarily provide an opportunity for participants to develop all five of the professional values identified in the HEA framework, particularly in regard to a commitment to relevant research and scholarship in teaching and learning (see Figure One).

\section{Figure One: UK Framework's Professional Values}

1. Respect for individual learners

2. Commitment to incorporating the process and outcomes of relevant research, scholarship and/or professional practice

3. Commitment to development of learning communities

4. Commitment to encouraging participation in higher education, acknowledging diversity and promoting equality of opportunity

5. Commitment to continuing professional development and evaluation of practice

However, it could be argued that the place for such commitment is in Postgraduate Certificates of Higher Education/Tertiary Teaching, of longer duration and intensity. Along these lines, attendees at the Australasian Foundations of University Teaching and Learning (FOUTL) Colloquia in 2003 and 2004, developed a Draft Framework for Professional Development for Higher Education Teaching (Foundations, 2004). This draft framework identifies Postgraduate Certificates as the place where scholarly practice (Boyer, 1990; Glassick, et.al., 1997) is most likely to occur. The draft Australasian framework suggests that FOUTL programmes (such as the programmes this paper looks at) should adopt a reflective practice theoretical dimension, in order to provide the groundwork for scholarly practice in teaching and learning that Postgraduate Certificates then build on.

One aspect of scholarly practice, as identified by Glassick, et.al. (1997) is "Clear Goals". Glassick, et.al., state that, "A scholar must be clear about the aims of his or her work" (p. 25). Extrapolating this out to a scholarly programme, then, any programme that aims to be scholarly should have realistic, achievable and clearly articulated goals and objectives. Two of the eight New Zealand universities provide easily accessible (that is, on the website or in a publicly available programme flyer) objectives for their IULT programmes (see Figure Two, below). However, four other universities provide a short course description that includes a goal along the lines of the following: "To introduce new academic staff to key concepts and strategies for university teaching and learning". One of these four universities also includes an aim of supporting staff in their reflective practice. 


\section{Figure Two: Objectives of New Zealand IULT Programmes}

\section{University One}

To introduce new-to-teaching staff to key concepts and strategies for university teaching and learning

\section{University Two}

To introduce participants to the learning and teaching principles and practices at [this university] and support them in their reflective practice

\section{University Three}

No specific objectives

\section{University Four}

To introduce new staff and inexperienced teachers to university teaching

\section{University Five}

At the completion of this seminar staff will be able to

- articulate their understanding of student learning and effective teaching practice, as supported by educational theory;

- identify key assessment concepts;

- identify a variety of strategies for gaining feedback on teaching practice; and

- design an effective learning experience for their students.

\section{University Six}

By the end of [this programme] academic staff should:

- Feel welcomed, formally and informally, into [this] community of learners and scholars

- Be aware of key institutional policies, systems, and procedures affecting academic work

- Be introduced to [this university's] core institutional values, strategic plan, and graduate attributes

- Have been provided with an overview of [this university's] diverse student population

- Know how and where to find information, resources and services available to support learning, teaching, and research

- Be able to identify and employ a variety of practical, easily-adapted tools for efficient, effective researchled teaching

- Have begun to develop professional and social support networks within [this university]

University Seven

To provide an overview to key aspects of teaching and learning

University Eight: No objective/s specified

Of the two universities whose full lists of objectives are publicly available, one ADU appears to be aiming to provide an holistic, broad-brush but inevitably shallow approach (limited by three short days) to learning about academic life at the university, while the other concentrates solely on the academic's teaching role and emphasises feedback and hands-on experience.

Along with a lack of clear objectives, no theoretical framework or underpinning is clear for most of the programmes, except arguably the two that mention directly, or imply a connection with, "reflective practice". The "atheoretical" (cf Tight, 2004) nature of these programmes could lead participants or outside observers to the conclusion that the "theory-in-action" (Schon, 1983) of many ADUs is "Teaching as Telling" (Ramsden, 2003, p. 115). Each programme may well be informed by any number of sound educational theories. However, with the apparent emphasis on providing an overview of key aspects of the university environment and introducing staff to ideas and tips, teaching in these programmes could be seen to be about transmitting information, presenting ideas rather than creating learning experiences, and focussing chiefly on presentation 
as the key teaching activity (in this instance, either by ADU staff or "guest speakers"). Clearly, this is an area that requires follow-up research to determine which theories actually influence and drive New Zealand ADU programmes and research.

\section{What some New Zealand new academics want}

The previous section briefly outlined what new academics in New Zealand universities receive from their ADUs, in terms of an introduction to the university teaching and learning environment. The following section looks at data from Victoria University of Wellington Orientation to Academic Life participants (2004-2006) to determine, in part, what it is that new academics themselves say they actually want.

An analysis of the espoused goals of participants in the February 2006 Orientation programme reveals what new academics thought would be useful in the 3-day programme, designed to introduce them to the university's academic environment. Thirty participants completed an exercise on the first day of the programme asking them to identify and prioritise up to five goals they hoped to achieve during the three days. The responses are summarised in the table below, in descending order by frequency of mention. Goals that were mentioned by only one person have not been included.

Table Four: VUW Participants' Goals for Orientation, February 2006

\begin{tabular}{|l|l|}
\hline Participants' Goals in Order of Priority & $\begin{array}{l}\text { Number of participants who } \\
\text { identified this as a goal }\end{array}$ \\
\hline Preparing and giving effective lectures & 14 \\
\hline The university's online learning management system & 12 \\
\hline Course Design and/or Coordination & 8 \\
\hline General teaching tips & 7 \\
\hline Time management/balancing teaching and research expectations & 6 \\
\hline Assessment, including marking guides & 6 \\
\hline Personal teaching styles, strengths and weaknesses & 5 \\
\hline New Zealand learning and teaching styles & 4 \\
\hline Student learning styles & 4 \\
\hline Small group teaching, including dealing with difficult students & 4 \\
\hline Grant applications - what, when, who can help & 3 \\
\hline University and ADU services & 3 \\
\hline Networking with colleagues & 2 \\
\hline Supervision tips & 2 \\
\hline Learning how to work the electronic lecterns/technical teaching equipment & 2 \\
\hline Promotion and probation expectations & 2 \\
\hline
\end{tabular}

While the programme was touted as an "Orientation to Academic Life," not merely an introductory teaching course, most participants clearly came expecting to be introduced to some key aspects of teaching and learning at university. Their goals encompassed teaching in general - lecturing tips, assessment, course design, etc - as well as what they perceived to be the more specific norms and expectations of this institution in terms of, for example, assessment, teaching and learning styles of VUW academics and students. Some participants' expectations were no doubt influenced by the skeletal outline and objectives of the 3-day programme which participants would have been able to read online beforehand, or in the flyer accompanying their personal letter of invitation (a timetable which emphasised teaching and learning). However, some participants also expressed a desire to learn about research requirements and possibilities, as well as supervision, grants and promotion - not mentioned in these resources/messages. 
Participants in February 2006 took part in a programme which aimed to introduce them to the VUW learning and teaching environment, provide some teaching tools, connect them with key people within the university, and expose them to various points of view about teaching and learning (views from the research, award-winning teachers, students, other academics, and themselves). Their reported satisfaction with the programme was high, with $87 \%$ of the 40 respondents finding the programme very or extremely useful, and $97 \%$ rating the quality of the overall programme as excellent or good. Similar evaluation results were received in 2005 and 2004 as well.

Several aspects of the 2006 programme had been adapted in response to participant feedback from evaluations in previous years, from follow-up phone calls to participants, and from focus groups held with the 2004 and 2005 participants at the end of each year. However, the following issues were identified by previous participants as areas where improvements still need to be made. Obviously, not all can be rectified by ADU programme changes alone, but should happen at either a departmental or individual level, or with the help of units like HR.

- Faculty or Department specific inductions (getting stationery, setting up a computer account, etc)

- A focus on teaching and learning in particular disciplines

- Information for new international staff on living in Wellington and New Zealand

- More tailored sessions for staff who already have teaching experience

- Mentoring opportunities, particularly for research

- Entitlements, expectations, and competition in terms of funding, leave and research time

Picking up on the third point, above, while two New Zealand institutions have experimented with offerings for new international staff, nothing formal is offered by any of the ADUs. For a few years, Victoria had an optional component called "New to New Zealand" in their "Orientation to Academic Life" programme, but lack of interest and mediocre evaluations of the usefulness of the session saw its demise in 2005. Similarly, the Director of the ADU at AUT reports that "New international academic staff were offered a special two-hour session at the conclusion of Orientation programme in semester one 2005, but attendance numbers were too low to be viable - discontinued in second semester. A short course "New to Auckland and NZ" is offered to students and staff by our Student Learning Centre (Te Tari Awhina), and a number of staff do attend that programme. (Email correspondence, 27 March 2006).

Furthermore, no New Zealand ADUs offer anything formal for new Maori staff, although the universities, departments, or Human Resources departments may well offer programmes, events, or networks of which the ADUs are not aware. Victoria's ADU initiated a monthly hui (meeting) for new female Maori academic staff in 2005 when it was discovered that six new female Maori academics had all begun new academic careers within a year of each other at Victoria. An unsuccessful bid for research funding was made to the TLRI Fund to develop and examine the impact of these hui, and they, and an accompanying Blog website are now organised and run by the women themselves. Victoria also has "Te Matawhanui," an organisation for all Maori staff, academic and general, that just re-launched in 2006 and which all Maori academic staff are actively encouraged to join.

Clearly, new academic staff, at least at Victoria University of Wellington, are keen for a holistic and discipline-based approach to introducing them to the university environment. More in-depth analysis of the existing VUW focus group data, and in-depth, follow-up interviews with some participants are planned for later this year to identify some ways forward in this regard. In the meantime, the proposed ideas for the draft framework below offer a starting point for discussion about developing a standards-based approach to short-course initial academic development 
programmes for new academic staff in New Zealand universities.

\section{Possibilities for a Draft New Zealand Framework}

Given the short time frame of most of New Zealand's introductory programmes for new academics, and the reality that these two to five day programmes are, in some instances, the only opportunity that ADUs have to make a significant impact on the beliefs, conceptions, perceptions, and behaviours of new academic staff, what should ADUs be aiming for in IULT programmes? Based on what is happening elsewhere, what the literature says new academics need, and what participants themselves are asking for, I recommend that the New Zealand ADU community collaborate on creating a framework for the development of standards-based IULT programmes. This framework should be theory-driven, research-led and contextually responsive, and should support the development of programmes that seek to meet the following criteria:

- Holistic (including all aspect of an academics' role, not just teaching and learning)

- Participant-driven, with achievable requirements

- Adequately prepared with clear goals, appropriate methods and effective presentation

- A launching pad that will catapult participants into wider AD programmes, including Postgraduate Certificates, with a "deep approach to learning" frame of mind

- Clearly woven into departmental and university-wide induction programmes and processes

These criteria may well form a basis for discussion around possible standards, and to further this discussion I also propose that the primary goals of any introductory New Zealand programme might be:

- to enable new academics to create connections and build networks, both within their disciplines and across the university;

- to build a launching pad for effective teaching that will have a positive impact on student learning;

- to provide a uniquely New Zealand experience, which honours the principles of the Treaty of Waitangi, celebrates the distinctive nature of the teaching-research nexus enshrined in legislation in New Zealand, and harnesses the relative homogeneity and smallness of the New Zealand university community; and

- to contribute to a happy AND successful start to new academics' careers and/or their time at our university.

Finally, the New Zealand IULT programmes should be "judged on the significance of [their] results" (Glassick, et.al., 1997, p. 29) and critically evaluated on a regular basis. To this end, the final section of this paper provides some suggestions for further research.

\section{Suggestions for further research}

Next steps should include in-depth case studies and/or reviews of all eight universities' programmes to provide an overview of their objectives, models and theoretical frameworks. Such case studies could include surveys, interviews, and focus groups with ADU staff, academics, and students at each institution. Taking such case studies a step further, we might also consider adopting a review framework which enables us to "improve the scholarly basis for our practice," as suggested by Kahn and Macdonald (2005). It is also important, given the lack of New Zealand research in this area, to ask how we might better evaluate the impact of our AD programmes on staff and students. It might be useful to consider Kreber and Brooks (2001) six possible points of focus for programme impact evaluation:

1. participants' perceptions/satisfaction

2. participants' beliefs about teaching and learning 
3. particpants' teaching performance

4. students' perceptions of staff's teaching performance

5. students' learning; and

6. effects on the culture of the institution.

\section{Conclusion}

New Zealand has witnessed a clear shift in tertiary education priorities, from academic staff/teaching-centred to student/learning-centred: the New Zealand Tertiary Education Strategy, 2002-2007, calls for "a stronger system focus on teaching capability and learning environments, to meet diverse learner needs" (STEP, 2002). Given this, New Zealand ADUs should ensure that their IULT programmes are "producing learning, not providing instruction," (Angelo, 1999) however short the programmes might be. IUTL programmes may be the only opportunity the ADUs have to meet with new academic staff. For this reason, the programmes and facilitators should model the best practice identified for making learning possible, not merely deliver information or instruction. ADUs should leave to the websites and handbooks the information academics can find themselves and provide them instead with opportunities to connect, network, survive, and start their career successfully. As Cranton suggests,

The most successful staff development programmes are likely to be those that assist staff in identifying their own learning needs, in pursuing their own learning goals, and in selfevaluating whether personal goals or objectives were meet. In such a self-directed learning environment the probability for transformative learning to occur (changes in one's beliefs and actions on the basis of critical reflection) may be the greatest" (Cranton, 1994, cited in Kreber and Brooks, 2001, p. 100).

New Zealand ADUs must also ensure that they engage in reflective critique which provides evidence of significant results for the IUTL programmes, such that they model the kind of scholarly practice they are encouraging in new academic staff. 


\section{References}

Angelo, T. A. (1999). Doing academic development as though we value learning most: Transformative guidelines from research and practice. pp. 111-122 in R. James, J. Milton \& R. Gabb (eds). Research and Development in Higher Education, 22: Cornerstones of Higher Education.

Boud, D. (1999). Situating academic development in professional work: Using peer learning. International Journal for Academic Development, 4 (1): 3-10.

Boyer, E. (1990). Scholarship reconsidered: Priorities of the professoriate. Washington: Carnegie Foundation for the Advancement of Teaching.

Dearn, J., Fraser, K. \& Ryan, Y. (2002, October). Investigation into the provision of professional development for university teaching in Australia: A discussion paper. DEST, Australia. http://www.dest.gov.au/archive/highered/pubs/uni teaching/uni teaching.pdf. Last accessed 31 March 2006.

Foundations Colloquium (2004). No author provided. Draft Framework for Professional Development for Higher Education Teaching. Last accessed 31 March 2006. http://www.flinders.edu.au/teach/foundations/colloquium2004/colloquium2004.htm

Gibbs, G. \& Coffey, M. (2004). The impact of training of university teachers on their teaching skills, their approach to teaching and the approach to learning of their students. Active Learning in Higher Education, 5 (1): 87-100.

Glassick, C., Huber, M.T., and Maeroff, G.I. (1997). Scholarship assessed: Evaluation of the professoriate. San Francisco: Jossey-Bass.

Higher Education Academy (HEA) (n.d.). The UK Professional Standards Framework for teaching and supporting learning in higher education. Last accessed 31 March 2006. http://www.heacademy.ac.uk/professionalstandards.htm.

Hicks, O. (1999). Integration of central and departmental development - reflections from Australian universities. International Journal for Academic Development, 4 (1): 43-51.

Ho, A., Watkins, D. and Kelly, M. (2001). The conceptual change approach to improving teaching and learning: An evaluation of a Hong Kong staff development programme. Higher Education, 42: 143-169.

Kahn, P. and Macdonald, R. (2005, November). Reviews of the impact of staff and educational development: A means to improve the scholarly basis for our practice. A workshop presented $9^{\text {th }}$ Annual SEDA Conference for Staff and Educational Developers, 16-17 November, 2005.

Kreber, C. and Brook, P. (2001). Impact evaluation of educational development programmes. International Journal for Academic Development, 6 (2): 96-108.

Nicholls, G. (2005). New lecturers' constructions of learning, teaching and research in higher education. Studies in Higher Education, 30 (5): 611-625.

Nyquist, J.D, et.al., (1999). On the road to becoming a professor: The graduate student experience. Change 13 (3): 18-27. 
Prebble, T., Hargraves, H., Leach, L., Naidoo, K., Suddaby, G., and Zepke, N. (2004). Impact of student support services and academic development programmes on student outcomes in undergraduate tertiary study: A synthesis of the research. Report to the Ministry of Education. Last accessed on 31 March 2006. http://www.minedu.govt.nz/goto/UgradStudOutcomesRpt.

Ramsden, P. (2003). Learning to teach in higher education. ( $2^{\text {nd }}$ ed). London and New York: Routledge Falmer.

Reid, A. (2002). Is there an 'ideal' approach for academic development? A paper presented at the International Consortium for Educational Developers (ICED) Conference, Perth, Western Australia, July 2002.

Roche, V. (2001). Professional development models and transformative change: A case study of indicators of effective practice in higher education. International Journal for Academic Development, 6 (2): 120-129.

Rust, C. (2000). Do initial training courses have an impact on university teaching? The evidence from two evaluative studies of one course. Innovations in Education and Training International, 37 (3): 254-263.

Schön, D. (1983) The Reflective Practitioner. How professionals think in action. London: Temple Smith.

Staniforth, D. \& Harland, T. (In Press). Contrasting views of induction: The experiences of new academic staff and their heads of department.

Statement of Tertiary Education Priorities (STEP). (2002).

http://www.tec.govt.nz/about tec/strategy/step/step.html. Last accessed 31 March 2006.

Sutherland, K (2004). New Zealand Foundations of University Teaching and Learning Programmes: An Overview. An invited presentation for the opening panel of the Foundations of University Teaching and Learning Colloquium, October 21-22 2004, Flinders University, Adelaide, Australia. Last accessed 31 March 2006.

http://www.flinders.edu.au/teach/foundations/colloquium2003/Presentations/NZExpFoundation s.doc.

Sutherland, K. (2003). Introduction to university teaching: The New Zealand experience. An invited presentation for the opening panel of the Foundations of University Teaching and Learning Colloquium, April 10-11 2003, Flinders University, Adelaide, Australia. http://www.flinders.edu.au/teach/foundations/colloquium2004/Presentations/KSAdelaideColloq uium04.ppt. Last accessed 31 March 2006.

Trowler, P. and Knight, P. (2000). Coming to know in higher education: Theorising faculty entry to new work contexts. Higher Education Research and Development, 19 (1): 27-42.

Trowler, P. and Knight, P. (1999). Organizational socialization and induction in universities: Reconceptualizing theory and practice. Higher Education, 37: 177-195.

Tight, M. (2004). Research into higher education: an a-theoretical community of practice? Higher Education Research and Development, 23 (4): 395-411. 